Research article Open Access

\title{
Mutation analysis of FANCD2, BRIP1/BACH1, LMO4 and SFN in familial breast cancer
}

\author{
Aaron G Lewis ${ }^{1}$, James Flanagan ${ }^{1}$, Anna Marsh¹, Gulietta M Pupo², Graham Mann², \\ Amanda B Spurdle1, Geoffrey J Lindeman ${ }^{3}$, Jane E Visvader ${ }^{4}$, Melissa A Brown ${ }^{5}$, \\ Georgia Chenevix-Trench ${ }^{1,6}$ and the Kathleen Cuningham Foundation Consortium for Research into \\ Familial Breast Cancer
}

\author{
1Department of Cancer Genetics, Queensland Institute of Medical Research, Brisbane, Queensland, Australia \\ ${ }^{2}$ Westmead Institute for Cancer Research, University of Sydney at Westmead Millennium Institute, Westmead Hospital, Westmead, New South \\ Wales, Australia \\ ${ }^{3}$ Peter MacCallum Cancer Centre, Melbourne, Victoria, Australia \\ ${ }^{4}$ VBCRC Laboratory, The Walter and Eliza Hall Institute of Medical Research, Melbourne, Victoria, Australia \\ ${ }^{5}$ School of Molecular and Microbial Sciences, University of Queensland, St Lucia, Queensland, Australia \\ ${ }^{6}$ Department of Pathology, University of Queensland, St Lucia, Queensland, Australia \\ Corresponding author: Georgia Chenevix-Trench, georgiaT@qimr.edu.au \\ Received: 16 Aug 2005 Accepted: 26 Sep 2005 Published: 21 Oct 2005 \\ Breast Cancer Research 2005, 7:R1005-R1016 (DOI 10.1186/bcr1336) \\ This article is online at: http://breast-cancer-research.com/content/7/6/R1005 \\ (c) 2005 Lewis et al.; licensee BioMed Central Ltd. \\ This is an Open Access article distributed under the terms of the Creative Commons Attribution License (http://creativecommons.org/licenses/by/ \\ 2.0), which permits unrestricted use, distribution, and reproduction in any medium, provided the original work is properly cited.
}

\begin{abstract}
Introduction Mutations in known predisposition genes account for only about a third of all multiple-case breast cancer families. We hypothesized that germline mutations in FANCD2, BRIP1/ $B A C H 1, L M O 4$ and SFN may account for some of the unexplained multiple-case breast cancer families.

Methods The families used in this study were ascertained through the Kathleen Cuningham Foundation Consortium for Research into Familial Breast Cancer (kConFab). Denaturing high performance liquid chromatography (DHPLC) analysis of the coding regions of these four genes was conducted in the youngest affected cases of 30 to 267 non-BRCA1/2 breast cancer families. In addition, a further 399 index cases were also screened for mutations in two functionally significant regions of the FANCD2 gene and 253 index cases were screened for two previously reported mutations in $B A C H 1$ (p. P47A and $p$. M299l).
\end{abstract}

Results DHPLC analysis of FANCD2 identified six silent exonic variants, and a large number of intronic variants, which tagged two common haplotypes. One protein truncating variant was found in $B R I P 1 / B A C H 1$, as well as four missense variants, a silent change and a variant in the $3^{\prime}$ untranslated region. No missense or splice site mutations were found in LMO4 or SFN. Analysis of the missense, silent and frameshift variants of FANCD2 and $B A C H 1$ in relatives of the index cases, and in a panel of controls, found no evidence suggestive of pathogenicity.

Conclusion There is no evidence that highly penetrant exonic or splice site mutations in FANCD2, BRIP1/BACH1, LMO4 or $S F N$ contribute to familial breast cancer. Large scale association studies will be necessary to determine whether any of the polymorphisms or haplotypes identified in these genes contributes to breast cancer risk.

\section{Introduction}

Pathogenic mutations in BRCA1, BRCA2, TP53, PTEN, ATM and $C H E K 2$ account for approximately a third of high-risk breast cancer families, suggesting that other breast cancer susceptibility genes exist [1-5]. Given the number of candidate breast cancer susceptibility genes, any approach to their identification needs to be focussed. Genes whose products are known to interact with BRCA1 and/or BRCA2, or are downregulated in breast tumours, are particularly attractive candidates, and can be prioritised for investigation.

$\mathrm{bp}=$ base pair; DHPLC = denaturing high performance liquid chromatography; FA = Fanconi anaemia; kConFab = Kathleen Cuningham Foundation Consortium for Research into Familial Breast Cancer; RT-PCR = reverse-transcription polymerase chain reaction; SFN = stratifin; SNP = single nucleotide polymorphism; UTR = untranslated region. 
FANCD2 is one of eight genes known to cause the fatal human autosomal recessive disorder Fanconi anaemia (FA) $[6,7]$. FA is a heterogenous condition characterised by progressive bone marrow failure, congenital abnormalities, hypersensitivity to DNA damaging agents and, most importantly, an increased risk of developing cancer [8]. There are currently eight cloned FA genes (FANCA, FANCC, FANCD1/ BRCA2, FANCD2, FANCE, FANCF, FANCG and FANCL), all of which interact with each other in a common cellular pathway $[6,7]$. Five of the FA proteins (FANCA, C, E, F, and G) form a constitutive complex in the nucleus of normal cells [9]. With the help of the recently identified ubiquitin ligase protein PHF9 (or FANCL), this multisubunit nuclear complex mediates the monoubiquitination of the FANCD2 protein at lysine 561 in response to the S-phase of the cell cycle or DNA damage [6]. The activated FANCD2 protein is then translocated to chromatin and DNA-repair foci, where it co-localises with other DNA repair proteins such as BRCA1, BRCA2, ATM, NBS1 and RAD51 [9]. Interestingly, this translocation has been recently identified to be BRCA1 dependent, suggesting that FANCD2 and BRCA1 interact in this process [6]. In response to ionising radiation, FANCD2 is also phosphorylated by ATM on serine 222, which leads to the activation of an S-phase checkpoint of the cell cycle [9]. FANCD2 is located at 3p25.3 and consists of 44 exons, encoding a protein of 1,451 amino acids. Houghtaling et al. [10] showed that FANCD2 homozygous and heterozygous mice display a high incidence of epithelial tumours, including mammary and ovarian carcinomas. These mice display other features found in BRCA2 mutant mice, including germ-cell defects, small size, and perinatal lethality [11]. FANCD2, like BRCA2, may, therefore, play an important role in the recombination DNA repair pathways [10]. The FA pathway has also been implicated in ovarian cancer, as the FANC-BRCA pathway was shown to be disrupted in a subset of ovarian tumour lines [12]. Furthermore, the 3p25-26 region of the human genome has been shown to have a high incidence of loss of heterozygosity in ovarian tumours [13]. Analysis of the FA genes (FANCA, B, C, D1, $D 2, E, F, G)$ in 88 non-BRCA1, non-BRCA2 breast cancer families failed to identify any penetrant mutations, but none of these families were known to share a haplotype around the relevant FANC genes, or to include cases of ovarian cancer [14].

BRIP1/BACH1 was first isolated and identified by using a glutathione S-transferase fusion protein containing the BRCT motifs and the carboxyl terminus of BRCA1. This protein was originally named $\mathrm{BACH} 1$ (for BRCA1-associated carboxy-terminal helicase 1), but is also known as BRIP1 (for BRCA1 interacting protein 1) [15]. The $B R I P 1 / B A C H 1$ gene maps to $17 q 22$ and contains 20 exons, encoding a protein of 1,249 amino acids. Amino acid residues 888 to 1,063 of BRIP1/ $\mathrm{BACH} 1$ interact with the BRCT domain of BRCA1 during the process of DNA repair [15]. Cantor et al. [15] screened the $B R I P 1 / B A C H 1$ gene for mutations in 21 sporadic breast/ ovarian cancer cell lines, and 65 individuals with early onset breast cancer. Two germline heterozygous missense variants (p. P47A and M299l) were detected in the germlines of two early onset breast cancer patients but no family members were available for segregation analysis. Both variants are within the helicase domain of $\mathrm{BACH} 1$ (residues 1 to 888), with P47A located in the highly conserved nucleotide binding box, and M299I situated between two other conserved motifs [15]. Two other studies looking at variants in the BRIP1/BACH1 gene in breast cancer families failed to find any highly penetrant mutations, although these studies were limited in their sample size, and the number of available samples from additional family members, and none of the families were known to share a haplotype around BRIP1/BACH1 [16,17].

LMO4 is a member of the LIM-only (LMO) family of transcription regulators. The four known members of this group (LMO1 to LMO4) are composed of two LIM domains and are thought to function as transcriptional cofactors via protein-protein interactions (reviewed in [18]). LMO1 and LMO2 overexpression is linked to T-cell tumourigenesis and LMO4 has been associated with breast oncogenesis, where overexpression is observed in approximately $50 \%$ of breast cancer cell lines and primary breast cancers [19]. Furthermore, overexpression of LMO4 induces mammary hyperplasia in transgenic mice and may be a predictor of poor outcome in breast cancer [20]. The presence of LMO4 in a complex containing the binding partners Ldb1, CtIP and the familial breast cancer tumour suppressor BRCA1 provides further compelling evidence for LMO4 playing a significant role in breast cancer pathogenesis [21], and activating mutations might be predicted to occur in some tumours and even in the germline of some patients. Although no activation mutations have been found, one somatic truncation mutation of LMO4 has been reported in a sporadic breast tumour [22]. This finding, as well as the deregulation of LMO4 expression in breast cancer and the interaction between LMO4 and the tumour suppressor BRCA1, prompted us to screen non-BRCA1/2 familial breast cancer cases for genetic alterations in LMO4 that may contribute to pathogenesis.

Stratifin (SFN; 14-3-3 $\sigma$; HME1) was first identified by serial analysis of gene expression (SAGE) analysis as an epithelial specific marker that was expressed at seven-fold lower levels in breast cancer cells compared to normal breast epithelium [23]. Recently, hypermethylation of SFN was detected in more than $90 \%$ of invasive breast cancers and was specifically associated with lack of expression [24]. In addition, methylation of this gene was detected in $83 \%$ of ductal carcinoma in situ and $38 \%$ of atypical hyperplasias but was unmethylated in all hyperplasias without atypia and normal breast epithelium obtained from patients without breast cancer [25]. Of most interest was the fact that SFN hypermethylation was also detected in the histologically normal adjacent breast epithelium in patients with breast cancer, suggesting that methylation of this gene may be an early event in breast cancer 
development. SFN is a negative regulator of cell cycle progression and is suggested to have an important function in preventing breast tumour cell growth, particularly at the G2 cell cycle checkpoint [26]. BRCA1 is a co-activator of SFN, and the expression of SFN is modulated by the BRCA1 status of the cell and requires intact BRCA1 and p53 to synergistically induce the optimal level of stratifin required for DNA damage response [27]. Interestingly, there is a nine-fold decreased expression of SFN in BRCA1- and BRCA2-related tumours compared to sporadic breast tumours [28]. SFN is located on 1 p36.11 and is encoded by a single 747 base pair (bp) exon; 1 p36 is a target of loss of heterozygosity in 16\% to $37 \%$ of sporadic breast tumours $[29,30]$ and in $32 \%$ to $35 \%$ of familial tumours [31]. To our knowledge there has been no report of mutation analysis of SFN in familial breast cancer.

We sought to carry out mutation analysis of FANCD2, BRIP1/ $B A C H 1, L M O 4$ and SFN in a large number of non-BRCA1/2 breast cancer families. For the biggest genes, FANCD2 and $B R I P 1 / B A C H 1$, we screened a smaller number of families, but included those in which the affected family members shared a haplotype around the gene of interest. We also screened additional index cases for mutations in the FANCD2 exons that contain the ATM phosphorylation (S222) and the FANCD2 monoubiquitination regions (K561), and the BRIP1/ $B A C H 1$ exons that contained the previously reported breast cancer-association variants, p. P47A and p. M299I.

\section{Materials and methods Multiple-case breast cancer families}

Multiple-case breast cancer families were ascertained through the Kathleen Cuningham Foundation Consortium for Research into Familial Breast Cancer (kConFab) [32]. The ascertainment criteria for families without mutations in BRCA1 or $B R C A 2$ were four or more cases of breast or ovarian cancer (Criteria 1), or two or more if one has 'high risk' features, such as breast cancer diagnosis at less than 40 years, male breast cancer, bilateral breast cancer, or ovarian and breast cancer in the same woman (Criteria 1B). In both cases, the criteria also require that two or more affected women are alive and that the families have four or more living, female, unaffected first or second degree relatives over the age of 18 . The index cases, defined as the youngest available breast cancer case, were tested by diagnostic laboratories for mutations in BRCA1 and $B R C A 2$ by a variety of methods estimated to be $75 \%$ sensitive, and a subset were fully sequenced for BRCA1 and BRCA2.

A subset of the index cases screened for mutations were included in a $10 \mathrm{cM}$ genome-wide search for novel breast cancer susceptibility genes in multiple case breast cancer families from which BRCA1 and BRCA2 mutations had been excluded by high-sensitivity methods and in which no haplotype was shared at either locus (data not shown). The index cases qualified for FANCD2 and BRIPIBACH1 mutation analysis if an individual family logarithm of the odds (LOD) score under heterogeneity or a non-parametric LOD score of $\geq 0.5$ had been obtained at any of the markers closest to or flanking the FANCD2 (D3S1304, D3S1263, D3S2338) or $B R I P I B A C H$ (D17S944, D17S949, D17S787) genes.

All 44 coding exons of FANCD2 were evaluated in 33 index cases from 30 non-BRCA1/2 multiple case breast cancer families. Three families contained two cases with the same age of onset of breast cancer and so both cases were screened. The families were selected because they contained one or more cases of ovarian cancer $(n=18)$, or because all of the affected individuals in the family shared a haplotype around the $3 p 25$ region $(n=12)$. The entire $B R I P 1 / B A C H 1$ coding sequence (19 exons) was evaluated in the index case of 75 breast cancer families in which all the affected individuals shared a haplotype around BRIP1/BACH1 on chromosome $17 q(n=7)$, or which had undergone complete sequencing of BRCA1 and BRCA2 ( $\mathrm{n}=68$ ). All three coding exons of $L M O 4$ were screened in the index cases from 247 non$B R C A 1 / 2$ breast cancer families, and the single coding exon of SFN was screened in the index cases from 92 non-BRCA1/ 2 breast cancer families. Index cases from an additional 164 families were screened for just 639 bp of the single SFN exon. Eight index cases were fully screened for FANCD2, BRIP1/ $B A C H 1$ and $L M O 4$ genes (and six of these for SFN as well), and 227 individuals from 222 families were screened for both LMO4 and SFN.

In addition, 399 index cases, from 356 non-BRCA1/2 breast cancer families (some had more than one index case because multiple women were affected at the same age), were screened for FANCD2 mutations in the ATM phosphorylation (exon 9) and the FANCD2 monoubiquitination (exon 19) regions. Of these additional index cases (from 231 families) that were used for additional FANCD2 screening, 253 were also screened for BRIP1/BACH1 mutations in exons 3 and 7, where the p. P47A and p. M299l breast cancer-associated variants are located.

We used as controls DNA from 93 unrelated, adult, female monozygotic twins (only one from each pair) selected from a sample of 3,348 twin pairs. The twins were almost exclusively of European origin and had been recruited through the Australian Twin Registry. Approvals were obtained from the Human Research Ethics Committees of the Queensland Institute of Medical Research, and for kConFab from the Peter MacCallum Cancer Centre and all other committees to which kConFab reports.

\section{Mutation analysis}

Primers were designed using the web-based program Primer3 [33] to amplify 43 amplicons covering the 44 exons of FANCD2 [GenBank: NT005927], 21 amplicons covering 19 exons of BRIP1/BACH1 gene [GenBank: NT010783.13], 
Table 1

FANCD2, BRIP1/BACH1, LMO4 and SFN primers

\begin{tabular}{|c|c|c|c|c|c|c|}
\hline Gene & Exon & Forward primer & Reverse primer & $\begin{array}{l}\text { Annealing } \\
\text { temp }\left({ }^{\circ} \mathrm{C}\right)\end{array}$ & $\begin{array}{l}\text { Amplicon } \\
\text { size (bp) }\end{array}$ & $\begin{array}{c}\text { DHPLC } \\
\text { temp }\left({ }^{\circ} \mathrm{C}\right)\end{array}$ \\
\hline \multirow[t]{38}{*}{ FANCD2 } & 1 & GGTGAGCCCAGCTTATTGC & GCCTCGAGAGACTACGACCA & 55 & 188 & 64 \\
\hline & 2 & CTTCAGCAACAGCGAAGTAGTCTG & GATTCTCAGCACTTGAAAAGCAGG & 50 & 421 & 56 \\
\hline & 3 & GGACACATCAGTTTTCCTCTC & GAAAACCCATGATTCAGTCC & 50 & 308 & 56 \\
\hline & $4 \& 5$ & TCATCAGGCAAGAAACTTGG & GAAGTTGGCAAAACAGACTG & 50 & 466 & 53,58 \\
\hline & 6 & GAGCCATCTGCTCATTTCTG & CCCGCTATTTAGACTTGAGC & 50 & 282 & 56 \\
\hline & 7 & CAAAGTGTTTATTCCAGGAGC & CATCAGGGTACTTTGAACATTC & 50 & 342 & 55,60 \\
\hline & 8 & GACCAGAAAGGCTCAGTTCC & CTGCAGCACATTACCCAGAA & 55 & 463 & 51,56 \\
\hline & 9 & CAGCTCTGCATTTCACACGTA & TGCAGTGATAGAACCCCCATA & 55 & 265 & 60,62 \\
\hline & 10 & TGCCCAGCTCTGTTCAAACC & AGGCAATGACTGACTGACAC & 50 & 219 & 59 \\
\hline & 11 & TGCCCGTCTATTTTTTGATGAAGC & TCTCAGTTAGTCTGGGGACAG & 50 & 391 & 56 \\
\hline & 12 & TCATGGTAGAGAGACTGGACTGTGC & ACCCTGGAGCAAATGACAACC & 55 & 432 & 53,58 \\
\hline & 13 & ATGGCAGGAACTCCGATCTT & CCTTATTCAGCATGCCCTGT & 55 & 363 & 56 \\
\hline & 14 & GGGCATGCTGAATAAGGTGT & GACAGTGGGAAGGCAAGCTA & 55 & 189 & 57 \\
\hline & 15 & GGGAGTGTGTGGAACAAATGAGC & AGTTTCTACAGGCTGGTCCTATTCC & 50 & 513 & 56 \\
\hline & 16 & AACGTGGAATCCCATTGATGC & TTTCTGTGTTCCCTCCTTGC & 58 & 378 & 57 \\
\hline & 17 & GATGGTCAAGTTACACTGGC & САССТСССАССАATTATAGTATTC & 54 & 381 & 57 \\
\hline & 18 & CTATGTGTGTCTCTTTTACAGGG & ААТСТTТСССАССАТАТTGC & 50 & 233 & 52,57 \\
\hline & 19 & CATACCTTCTTTTTGCTGTGC & CCACAGAAGTCAGAATCTCCACG & 48 & 198 & 59 \\
\hline & 20 & ACACACCGGGGAATGTTGT & CTGCAGGTTGGGTGACAGAG & 53 & 341 & $49,54,59$ \\
\hline & 21 & GAGTTTGGGAAAGATTGGCAGC & TGTAGTAAAGCAGCTCTCATGC & 54 & 231 & 59 \\
\hline & 22 & АCACTCTGCACTGCCСTTTT & GAAAGAAGCTGTGGGACTGG & 55 & 239 & 60 \\
\hline & 23 & TGGTTTTCCCTGTAGCCTTG & CTCAACTTCCCCACCAAGAG & 55 & 294 & 60 \\
\hline & 24 & TTGTGTTCCCTATGTATGTGGAG & TTGATCTGCCСTTTCCСTAA & 54 & 269 & 58 \\
\hline & 25 & CAGCTAGCTCCAGAGGCAAC & TGCACAATAAGTGAAACATCCT & 54 & 229 & 58 \\
\hline & 26 & TTCATAGACATCTCTCAGCTCTG & GTTTTGGTATCAGGGAAAGC & 52 & 283 & 52,57 \\
\hline & 27 & GCCATGCTTGGTAATTTTGG & TTCCAATTACTGATGCCATGAT & 55 & 319 & 57 \\
\hline & 28 & TTGTTTTCTGAGGGCAATGA & TGGGATGTCACAAACCTTCA & 55 & 230 & 52,57 \\
\hline & 29 & GGTCTTGATGTGTGACTTGTATCCC & CCTCAGTGTCACAGTGTTCTTTGTG & 58 & 446 & 51,56 \\
\hline & 30 & CATGAAATGACTAGGACATTCC & CTACCCAGTGACCCAAACAC & 52 & 280 & 60 \\
\hline & 31 & GACTCCATTGCGAACCCTTA & CAGCCAAAAATGAAACCTCA & 55 & 260 & 58 \\
\hline & 32 & TGAGGTTTCATTTTTGGGTGA & GTGCCTTGGTGACTGTCAAA & 55 & 268 & 58 \\
\hline & 33 & TTGATGGTACAGACTGGAGGC & AAGAAAGTTGCCAATCCTGTTCC & 50 & 273 & 58 \\
\hline & 34 & AGCACCTGAAAATAAGGAGG & GCCCAAAGTTTGTAAGTGTGAG & 52 & 342 & 52,57 \\
\hline & 35 & TGTTAGACCGGGAACGTCTT & TTGGCTCATTGGAAGAAACC & 55 & 257 & 54,59 \\
\hline & 36 & TCTTCCAATGAGCCAAATAGC & CCCAGCCTGATGATGATTCT & 55 & 450 & 58 \\
\hline & 37 & AGAGGTAGGGAAGGAAGCTAC & CCAAAGTCCACTTCTTGAAG & 50 & 232 & 60 \\
\hline & 38 & GATGCACTGGTTGCTACATC & CCAGGACACTTGGTTTCTGC & 52 & 274 & 58 \\
\hline & 39 & ACACTCCCAGTTGGAATCAG & CTTGTGGGCAAGAAATTGAG & 54 & 369 & 54,59 \\
\hline
\end{tabular}


FANCD2, BRIP1/BACH1, LMO4 and SFN primers

\begin{tabular}{|c|c|c|c|c|c|c|}
\hline & 40 & TGGGCTGGATGAGACTATTC & CCAAGGACATATCTTCTGAGCAAC & 52 & 222 & 59 \\
\hline & 41 & TGATTATCAGCATAGGCTGG & GATCCCCCAATAGCAACTGC & 52 & 270 & 54,59 \\
\hline & 42 & CATTCAGATTCACCAGGACAC & CCTTACATGCCATCTGATGC & 54 & 226 & 59 \\
\hline & 43 & ААССТТСТССССТАТТАССС & GGAAAATGAGAGGCTATAATGC & 52 & 434 & 58 \\
\hline & 44 & TGTATTCCAGAGGTCACCCAGAGC & CCAGTAAGAAAGGCAAACAGCG & 59 & 234 & 58 \\
\hline \multirow[t]{21}{*}{$B R I P 1 / B A C H 1$} & 2 & TTCTTTGTAAGGCGTGTCTCAA & ATACTCAATGTACTTTATGGGTCA & 50 & 246 & 55 \\
\hline & 3 & TTGTTGTGTTCCCTGGAGTG & GACAGCATGGCTGAACCAGT & 55 & 325 & 56 \\
\hline & 4 & CTGGGTGAACTGGGCTGTAG & CAACTGACCCAGGCAAAATA & 55 & 281 & 52,57 \\
\hline & 5 & AAGCCTTACATCCTGGTTCC & CTAACTGGGTTATTTACTGCCAAT & 54 & 254 & 55 \\
\hline & 6 & GAGCTGTTTTGGCCTTTGAG & TTCCTTCTTTAAAACTGAACAATGG & 55 & 239 & 56 \\
\hline & 7 & TTCCATGTGAGGTTTGATAACG & GCAGTTAATTTGATTTTCCGAAG & 55 & 481 & 53,58 \\
\hline & 8 & GCCTTGTGGCTTTAATGATG & САTCTCCATGAGTAGGAAGAAGGT & 55 & 373 & 57 \\
\hline & 9 & TGAAATATCTTGCCTGCTGTTG & TTTTTCATATAAAGGCAGCACAA & 55 & 321 & 52,57 \\
\hline & 10 & GATCAACGCATGACAATAATGA & AATTCACTAAATACGTTTCACAGGT & 50 & 270 & 55 \\
\hline & 11 & СССТСССААССССТСТАТАС & TGCTAGCATCCAAATTAGGCTAT & 55 & 258 & 54 \\
\hline & 12 & TGGGAAGGTACCAGCTCTTT & TGCTGGTACTGAGCAAGAAGAC & 55 & З3З & 56 \\
\hline & 13 & TCAGACTCCTAGACTCAAGCGAT & TTACTTGCTGGCACTTCAGG & 54 & 364 & 54,59 \\
\hline & 14 & CATGCCTTTTTCAGGCATAA & TTGCСTCTACCCTAGGAAGC & 50 & 318 & 53,58 \\
\hline & 15 & GCCGTAGTCACATTGGCTTA & TTTTCACCAGACCATGAAATAA & 50 & 278 & 56 \\
\hline & 16 & TTCTGAGAATTTTGGATATGCTTTTT & TGCTGAAAGACTTGCACAATG & 55 & 319 & 57 \\
\hline & 17 & TTGAGATCACACAGCTGATTAGTTA & CCAGTTCCTATGGTTCCAGTT & 55 & 458 & 50,55 \\
\hline & 18 & CTGTCCCACTGGAAAACTGG & TCTGCTGTGAAATACTGTGCTT & 50 & 297 & 54 \\
\hline & 19 & GGTTACTTCACTAGAAAAAGCAAGTG & TCAAAGGTAAATGGGAAGAACTTT & 55 & 456 & 56 \\
\hline & $20 \mathrm{a}$ & GCAATTATGTTAGCTAGGAGCAGA & TCAAAATCTCTATTTGAAGTGGACTG & 55 & 516 & 52,57 \\
\hline & $20 b$ & TGAACATCCGCTCTGTTCTG & TGCAATCCTCAGCTTTCACT & 55 & 305 & 55 \\
\hline & $20 c$ & AACAATTCAGATTGCATTTTAGC & GAGTTTAACATAAGCATGATGAC & 50 & 328 & 53 \\
\hline \multirow[t]{3}{*}{ LMO4 } & 2 & тTTСтСтСССТGтССССтTС & CCCCATCTCCAGGAAAGAC & 55 & 304 & 59,64 \\
\hline & 3 & CCAAAGGGATGCCCAGAGT & GCCCCCATGTAGGTAGGAAA & 64 & 254 & 55,60 \\
\hline & 4 & CCTTGTTTTCAGTGGGTTTG & GGTTGAACCTTCCAACTTGC & 55 & 246 & 59 \\
\hline \multirow[t]{3}{*}{ SFN } & $1 \mathrm{a}$ & GCCAAGAGCAGGAGAGACAC & ATGCGCTTCTTGTCGTCAC & 60 & 510 & 63 \\
\hline & $1 \mathrm{~b} .1$ & GAGAGCCGGGTCTTCTACCT & TGATGAGGGTGCTGTCTTTG & 62 & 316 & 62 \\
\hline & $1 \mathrm{~b} .2$ & TCTCTCTGGCCAAGACCACT & TCCСАССССАТАСТАGTССТС & 64 & 249 & 63 \\
\hline
\end{tabular}

DHPLC, denaturing high performance liquid chromatography.

three amplicons for the three exons of LMO4 [GenBank: NM 006769] and three amplicons for the single coding exon of SFN [GenBank: NM006142]. PCR products were amplified from $15 \mathrm{ng}$ of genomic DNA using AmpliTaq Gold (PE Applied Biosystems, Forest City, CA, USA) in a final volume of $20 \mu \mathrm{L}$.
The amplification of fragments was optimised as needed by adjusting the $\mathrm{MgCl}_{2}$ concentration, adding $1 \mathrm{M}$ Betaine, or by lowering the annealing temperature. 
Table 2

\begin{tabular}{|c|c|c|c|c|c|}
\hline Segment & Nucleotide change $^{a}$ & Protein effect & $\begin{array}{l}\text { No. of heterozygous } \\
\text { cases }\end{array}$ & $\begin{array}{l}\text { Frequency in controls } \\
(\mathrm{n}=93)\end{array}$ & $\begin{array}{l}\text { Reported in SNPperb or FA } \\
\text { database }\end{array}$ \\
\hline- & $-82 G>A$ & & $1 / 33$ & Not tested & No \\
\hline- & $-155 G>A$ & & $1 / 33$ & Not tested & No \\
\hline- & $-157 G>A$ & & $9 / 33$ & Not tested & No \\
\hline- & $-158 \mathrm{C}>\mathrm{T}$ & & $1 / 33$ & Not tested & No \\
\hline- & $-160 G>A$ & & $1 / 33$ & Not tested & No \\
\hline Intron 5 & $379-6 \mathrm{del}$ TT & & $11 / 33$ & Not tested & No \\
\hline Exon 9 & $633 \mathrm{C}>\mathrm{T}$ & $|211|$ & $1 / 432$ & Not tested & No \\
\hline Intron 9 & $694+17 \mathrm{G}>\mathrm{C}$ & & $127 / 432$ & Not tested & No \\
\hline Intron 10 & $784-19 \mathrm{C}>\mathrm{T}$ & & $11 / 33$ & Not tested & No \\
\hline Intron 12 & $990-38 \mathrm{C}>\mathrm{G}$ & & $11 / 33$ & Not tested & No \\
\hline Exon 14 & $1122 A>G$ & V374V & $11 / 33$ & Not tested & Yes \\
\hline Intron 16 & $1414-9 \mathrm{C}>\mathrm{T}$ & & N/A & Not tested & No \\
\hline Intron 16 & $1414-23 \mathrm{~T}>\mathrm{C}$ & & N/A & Not tested & No \\
\hline Intron 16 & $1414-89 \mathrm{~T}>\mathrm{A}$ & & N/A & Not tested & Yes \\
\hline Intron 16 & $1414-117 \mathrm{~A}>\mathrm{T}$ & & N/A & Not tested & No \\
\hline Intron 16 & $1414-125 G>A$ & & N/A & Not tested & No \\
\hline Intron 16 & $1414-136 \mathrm{C}>\mathrm{T}$ & & N/A & Not tested & No \\
\hline Exon 17 & $1440 \mathrm{~T}>\mathrm{C}$ & $\mathrm{H} 480 \mathrm{H}$ & N/A & Not tested & Yes \\
\hline Exon 17 & $1509 \mathrm{C}>\mathrm{T}$ & N503N & N/A & Not tested & Yes \\
\hline Intron 21 & $1828+34 \mathrm{C}>\mathrm{T}$ & & $2 / 33$ & Not tested & No \\
\hline Intron 22 & $2021+10 \mathrm{G}>\mathrm{T}$ & & $1 / 33$ & Not tested & No \\
\hline Intron 22 & $2021+31 \mathrm{C}>\mathrm{T}$ & & $16 / 33$ & Not tested & Yes \\
\hline Intron 22 & $2021+100 A>G$ & & $1 / 33$ & Not tested & No \\
\hline Exon 23 & $2148 \mathrm{C}>\mathrm{G}$ & T716T & $1 / 33$ & Not tested & No \\
\hline Intron 24 & $2270-28 \mathrm{G}>\mathrm{T}$ & & $11 / 33$ & Not tested & No \\
\hline Intron 30 & $2976+36 \mathrm{~T}>\mathrm{C}$ & & $11 / 33$ & Not tested & Yes \\
\hline Intron 30 & 2977-39 C>T & & $1 / 33$ & Not tested & No \\
\hline Exon 35 & $3558 \mathrm{C}>\mathrm{G}$ & L1186L & $1 / 33$ & $0 / 93$ & No \\
\hline Intron 38 & $3850-203 \mathrm{C}>\mathrm{T}$ & & $11 / 33$ & Not tested & No \\
\hline Intron 42 & $4185+33 \mathrm{~T}>\mathrm{C}$ & & $11 / 33$ & Not tested & Yes \\
\hline Intron 43 & $4281+97 A>G$ & & $11 / 33$ & Not tested & No \\
\hline 3' UTR & $4359 \mathrm{C}>\mathrm{T}$ & 3' UTR & $15 / 33$ & Not tested & No \\
\hline
\end{tabular}

aGenBank accession number NT005927. bVariants have been previously reported in the SNP database SNPper [44] or Fanconi Anemia (FA) Mutation Database [45]. UTR, untranslated region.

For LMO4, cycling conditions for the exon 2 and exon 4 amplicons were $94^{\circ} \mathrm{C}$ for 12 minutes, followed by four sets of four cycles of $94^{\circ} \mathrm{C}$ for $30 \mathrm{~s}, 63^{\circ} \mathrm{C}$ to $57^{\circ} \mathrm{C}$ for $45 \mathrm{~s}$ and $72^{\circ} \mathrm{C}$ for
$30 \mathrm{~s}$, with the annealing temperature dropping $2^{\circ} \mathrm{C}$ after each set of four cycles, followed by 30 cycles of $94^{\circ} \mathrm{C}$ for $30 \mathrm{~s}$, $55^{\circ} \mathrm{C}$ for $45 \mathrm{~s}$ and $72^{\circ} \mathrm{C}$ for $30 \mathrm{~s}$, and a final extension of $72^{\circ} \mathrm{C}$ 
Table 3

\begin{tabular}{|c|c|c|c|c|c|c|}
\hline Gene & $\begin{array}{l}\text { Sequence } \\
\text { variant }\end{array}$ & Location & $\begin{array}{l}\text { Conserved in } \\
\text { mouse }^{\mathrm{a}}\end{array}$ & $\begin{array}{l}\text { Predicted effect on } \\
\text { mRNA structureb }\end{array}$ & $\begin{array}{l}\text { Predicted effect on } \\
\text { consensus splice sites }^{c}\end{array}$ & $\begin{array}{l}\text { Predicted effect on } \\
\text { exonic splice site }^{d}\end{array}$ \\
\hline \multirow[t]{3}{*}{ FANCD2 } & $633 \mathrm{C}>\mathrm{T}$ & Exon 9 & Yes & None & None & No change \\
\hline & $2148 C>G$ & Exon 23 & No & None & None & $\begin{array}{l}\text { Gains SRp55, changes } \\
\text { SF2/ASF }\end{array}$ \\
\hline & $3558 C>G$ & Exon 35 & No & $\begin{array}{l}\text { Slight shortening of side } \\
\text { branch }\end{array}$ & Loss of exon 35 donore & $\begin{array}{l}\text { Gains SC35, loses SF2/ } \\
\text { ASF }\end{array}$ \\
\hline \multirow[t]{5}{*}{$B R I P 1 / B A C H 1$} & $430 \mathrm{G}>\mathrm{A}$ & Exon 5 & Yes & None & None & $\begin{array}{l}\text { Loses SRp55 and } \\
\text { SRp40, gains SF2/ } \\
\text { ASF }\end{array}$ \\
\hline & $584 \mathrm{~T}>\mathrm{C}$ & Exon 6 & No & $\begin{array}{l}\text { Completely changes } \\
\text { mRNA structure }\end{array}$ & None & Loses SRp40 \\
\hline & $3401 \mathrm{delC}$ & Exon 20 & Yes & None & None & No change \\
\hline & $3464 \mathrm{G}>\mathrm{A}$ & Exon 20 & No & $\begin{array}{l}\text { Loss of one cluster of } \\
\text { stem loops, gain of } \\
\text { another }\end{array}$ & None & $\begin{array}{l}\text { Loses SRp40 and SF2/ } \\
\text { ASF }\end{array}$ \\
\hline & $3782 \mathrm{~T}>\mathrm{C}$ & 3' UTR & No & $\begin{array}{l}\text { Additional stem loop in } \\
\text { middle of structure }\end{array}$ & & \\
\hline \multirow[t]{10}{*}{ SFN } & $748 G>C$ & 3' UTR & No & $\begin{array}{l}\text { Change in branch } \\
\text { position }\end{array}$ & & \\
\hline & $765 \mathrm{C}>\mathrm{T}$ & 3' UTR & Yes & $\begin{array}{l}\text { Change in branch } \\
\text { position }\end{array}$ & & \\
\hline & $766 \mathrm{C}>\mathrm{A}$ & 3' UTR & Yes & $\begin{array}{l}\text { Loss of major side } \\
\text { branch }\end{array}$ & & \\
\hline & $767 \mathrm{C}>\mathrm{T}$ & 3' UTR & Yes & No change & & \\
\hline & $775 \mathrm{C}>\mathrm{A}$ & 3' UTR & Yes & No change & & \\
\hline & $776 \mathrm{C}>\mathrm{T}$ & 3' UTR & Yes & No change & & \\
\hline & $777 \mathrm{C}>\mathrm{T}$ & 3' UTR & Yes & No change & & \\
\hline & $786 \mathrm{C}>\mathrm{A}$ & 3' UTR & Yes & $\begin{array}{l}\text { Change in branch } \\
\text { position }\end{array}$ & & \\
\hline & $787 \mathrm{C}>\mathrm{A}$ & 3' UTR & Yes & No change & & \\
\hline & $792 \mathrm{C}>\mathrm{T}$ & 3' UTR & Yes & No change & & \\
\hline
\end{tabular}

aAccording to UCSC Genome Bioinfomatics [36]. bAccording to mFOLD [39].

CAccording to SpliceSiteFinder [41] and BDGP Splice Site Prediction [37].

dAccording to ESE Finder [38]. eAccording to BDGP Splice Site Prediction [37], but not SpliceSiteFinder [41]. UTR, untranslated region.

for 7 minutes. Cycling conditions for exon 3 were $94^{\circ} \mathrm{C}$ for 12 minutes, followed by four sets of 4 cycles of $94^{\circ} \mathrm{C}$ for $30 \mathrm{~s}$, $72^{\circ} \mathrm{C}$ to $66^{\circ} \mathrm{C}$ for $45 \mathrm{~s}$ and $72^{\circ} \mathrm{C}$ for $30 \mathrm{~s}$, with the annealing temperature dropping $2^{\circ} \mathrm{C}$ after each set of 4 cycles, followed by 30 cycles of $94^{\circ} \mathrm{C}$ for $30 \mathrm{~s}, 64^{\circ} \mathrm{C}$ for $45 \mathrm{~s}$ and $72^{\circ} \mathrm{C}$ for 30 $\mathrm{s}$, and a final extension of $72^{\circ} \mathrm{C}$ for 7 minutes. The same fourstep touchdown protocol used for the amplification of $L M O 4$ was also used for screening FANCD2, BACH1 and SFN (Table 1). The SFN exon was screened in three PCR fragments. SFN1a and SFN1b.1 were screened by denaturing high performance liquid chromatography (DHPLC) in 267 index cases. SFN1b.2 could not be screened successfully using DHPLC and so a subset of 92 cases, chosen based on DNA availability, were sequenced directly for this amplicon.
Amplicons were then denatured at $95^{\circ} \mathrm{C}$ for five minutes and cooled to $60^{\circ} \mathrm{C}$ over 30 minutes $\left(1^{\circ} \mathrm{C} /\right.$ minute) prior to injection onto the Varian Helix System (Varian, Walnut Creek, CA, USA). DHPLC was carried out at the recommended melt temperature for each exon (Table 1) as determined by the Stanford melt algorithm [34,35]. Analysis of the DHPLC results was performed using the Star Workstation version 5 (Varian). Samples that produced a heterozygous peak or an aberrant shift in retention time and/or peak shape were confirmed by DHPLC and re-amplified for sequencing. DNA sequencing was performed with both forward and reverse primers using the ABI Prism Big Dye Terminator cycle Sequencing Ready reaction kit (PE Applied Biosystems) and analysed on an $A B I$ 377 sequencer. Coding variants and variants located near the exon/intron boundary, were analysed in silico for amino acid 
changes, conservation in the mouse homologue (UCSC Genome Bioinfomatics [36]), predicted splicing defects (BDGP Splice Site Prediction [37], SpliceSiteFinder [41], and ESE Finder [38]), and predicted mRNA folding changes (mFOLD [39]).

All available family members' DNA samples were genotyped for any missense and frameshift variants, and for variants that appeared to lose a splice site, or have exonic splicing enhancer and/or mRNA folding changes, as predicted by the above web-based programs. Frameshift variants, missense variants, or variants predicted to affect splicing were further screened by DHPLC in 93 controls. Individuals carrying the rare FANCD2 variants, c. $633 \mathrm{C}>\mathrm{T}$, c. $1828+34 \mathrm{C}>\mathrm{T}$, c. $2148 \mathrm{C}>\mathrm{G}$, c. $2021+10 \mathrm{G}>\mathrm{T}$, and c. $3558 \mathrm{C}>\mathrm{G}$, were also sequenced for the common c. $694+17 \mathrm{G}>\mathrm{C}$ variant in exon 9 to determine on which haplotype these rare variants occurred.

\section{Results \\ FANCD2}

DHPLC analysis of FANCD2 in the 33 index cases from 30 breast and ovarian cancer families, and of exons 9 and 19 (containing the ATM phosphorylation site and the FANCD2 monoubiquitination site, respectively) in a further 399 non$B R C A 1 / 2$ index cases, identified 32 germline sequence alterations, most of which were novel (Table 2). Analysis of sequencing results identified 25 intronic variants, 6 silent coding variants, and another variant located within the 3 ' untranslated region (UTR).

The c.633 C>T and c. $2148 \mathrm{C}>\mathrm{G}$ variants did not appear by in silico analyses to affect mRNA folding or the concensus splice site sequences, as predicted by the BDGP Splice Site Prediction, SpliceSiteFinder, and mFOLD web-based programs (Table 3). c.2148 C>G was predicted to change the SF2/ASF exon enhancer sites and gain a SRp55 enhancer site. Because this nucleotide is not conserved in the murine Fancd2 gene, however, the functional significance of these changes remains unclear. The c. $3558 \mathrm{C}>\mathrm{G}(\mathrm{L} 1186 \mathrm{~L})$ variant, located 3 bp 5 ' of the end of exon 35, was predicted to result in a gain of a SC35 exonic splicing enhancer site, and a loss of a SF2/ASF site, and also subtly changing the predicted mRNA folding. In addition, the BDGP Splicing program predicted that the variant causes a complete loss of the donor site for exon 35 splicing, although this was not predicted by SpliceSiteFinder, consistent with the more sensitive algorithm of the BDGP splicing program [37]. To address this further we performed RT-PCR analysis with lymphoblastoid cell line RNA but found no evidence for altered splicing of this transcript (data not shown). The c. $3558 \mathrm{C}>\mathrm{G}$ variant was found in a family with five cases of breast cancer, of whom two also had ovarian cancer. DNA was available from two additional affected relatives of the index case (her daughter and cousin). The variant was carried by the daughter (affected at age 27 years) but not by the cousin (affected at age 34 years), nor by
Table 4

\section{FANCD2 haplotypes}

\begin{tabular}{lll}
\hline \multicolumn{2}{l}{ Haplotype } & Common or rare \\
\hline A & - - CTGGTCTCGCCGCC & Common \\
B & TTGCCAGTCTACCGCC & Common \\
C & TTGCCAGTCTATCGCC & Rare \\
D & TTGCCAGTCTACTGCC & Rare \\
E & TTGCCAGTCTACCTCC & Rare \\
F & TTGCCAGTCTACCGGC & Rare \\
G & TTGCCAGTCTACCGCG & Rare \\
\hline
\end{tabular}

The two common haplotypes were distinguishable by the single nucleotide polymorphisms c. 379-6 delTT, c. $694+17 \mathrm{C}>\mathrm{G}$, c. 784 $19 \mathrm{C}>\mathrm{T}$, c. $990-38 \mathrm{C}>\mathrm{G}$, c. $1122 \mathrm{~A}>\mathrm{G}$, c. $2270-28 \mathrm{G}>\mathrm{T}$, c. $2976+36$ T >C, c. $3850-203$ C>T, c. $4185+33$ T>C, and c. $4281+97 \mathrm{~A}>\mathrm{G}$. The rare haplotypes all occurred on the haplotype $B$ background and were represented by the rare variants, c. $633 \mathrm{C}>\mathrm{T}$, c. $1828+34 \mathrm{C}>\mathrm{T}$, c. $2021+10 \mathrm{G}>\mathrm{T}$, c. $2148 \mathrm{C}>\mathrm{G}$, and c. 3558 C>G. Letters A-G represent the seven different FANCD2 haplotypes.

any of the four unaffected female relatives (ages 22 to 57 years), nor by four male unaffected relatives. The c. $3558 \mathrm{C}>\mathrm{G}$ variant was not found using DHPLC in any of 93 matched twin controls. The other FANCD2 coding variants, c. $1122 \mathrm{~A}>\mathrm{G}, \mathrm{c}$. 1440 T >C, c. 1509 C >T, and the 3' UTR variant c. 4359 C>T were all common and/or previously reported as a single nucleotide polymorphism (SNP) and, therefore, no in silico analyses were conducted.

Two common haplotypes of $F A N C D 2$ were identified, represented by c. $379-6$ delTT, c. $694+17$ C>G, c. $784-19$ C>T, c. $990-38 \mathrm{C}>\mathrm{G}$, c. $1122 \mathrm{~A}>\mathrm{G}$, c. $2270-28 \mathrm{G}>\mathrm{T}$, c. $2976+36$ $\mathrm{T}>\mathrm{C}$, c. $3850-203 \mathrm{C}>\mathrm{T}$, c. $4185+33 \mathrm{~T}>\mathrm{C}$, and c. $4281+97$ $A>G$ (Table 4). We were unable to calculate the exact frequencies of each of the haplotypes because DHPLC did not distinguish the two homozygotes from each other. Sequencing showed that the rare variants, c. $633 \mathrm{C}>\mathrm{T}$, c. $1828+34$ C $>$ T, c. $2148 \mathrm{C}>\mathrm{G}$, c. $2021+10 \mathrm{G}>\mathrm{T}$ and c. $3558 \mathrm{C}>\mathrm{G}$, were all found on the common haplotype that corresponds to the reference sequence found on the NCBI database [42].

\section{BRIP1/BACH1}

A total of 10 nucleotide variants, four of which have not been previously reported, were identified in $B R I P 1 / B A C H 1$ among 75 non-BRCA1/2 index cases (Table 5). Six of these variants were exonic, of which one was a single base-pair deletion, four resulted in amino acid substitutions and one was silent (Table 5). Three of the missense variants, c. $430 \mathrm{G}>\mathrm{A}$ (p. A144T), c. 584 T>C (p. L195P) and c. 3464 G>A (p. G1155E), and the deletion variant c. $3401 \mathrm{del} C$ were absent in 93 controls. The c. $584 \mathrm{P}>\mathrm{C}$ (p. L195P) variant has been reported previously in an early onset breast cancer case, but not in controls [17]. In silico analyses of c. $430 \mathrm{G}>\mathrm{A}$ (p. A144T), c. $584 \mathrm{~T}>\mathrm{C}$ (p. L195P) and c. 3464 G>A (p. G1155E) predicted that they 
Table 5

\begin{tabular}{|c|c|c|c|c|c|}
\hline Segment & Nucleotide change ${ }^{a}$ & Protein effect & $\begin{array}{c}\text { No. of heterozygous } \\
\text { cases }\end{array}$ & Controls & Reported in SNP perb \\
\hline Intron 4 & $379-28 \mathrm{G}>\mathrm{A}$ & & $1 / 75$ & $1 / 93$ & Yes \\
\hline Exon 5 & $430 \mathrm{G}>A$ & $\mathrm{~A} 144 \mathrm{~T}$ & $1 / 75$ & $0 / 93$ & No \\
\hline Intron 5 & $508-31 C>G$ & & $23 / 75$ & $26 / 93$ & Yes \\
\hline Exon 6 & $517 \mathrm{C}>\mathrm{T}$ & $\mathrm{R} 173 \mathrm{C}$ & $1 / 75$ & $1 / 93$ & Yes \\
\hline Exon 6 & $584 T>C$ & L195P & $1 / 75$ & $0 / 93$ & Yes \\
\hline Intron 12 & $1795-47 \mathrm{C}>\mathrm{G}$ & & $27 / 75$ & Not tested & Yes \\
\hline Exon 20 & $3401 \mathrm{delC}$ & frameshift & $1 / 75$ & $0 / 93$ & No \\
\hline Exon 20 & $3411 \mathrm{~T}>\mathrm{C}$ & $\mathrm{T} 1137 \mathrm{~T}$ & $40 / 75$ & $34 / 93$ & Yes \\
\hline Exon 20 & $3464 \mathrm{G}>\mathrm{A}$ & G1155E & $1 / 75$ & $0 / 93$ & No \\
\hline Exon 20 & $3782 \mathrm{~T}>\mathrm{C}$ & 3' UTR & $1 / 75$ & Not tested & No \\
\hline
\end{tabular}

aGenBank accession number NT010783.13. bVariants have been previously reported in the SNP database SNPper [42]. UTR, untranslated region.

may affect mRNA folding and exonic splicing enhancers, but have no affect on the consensus splice sites (Table 3). The 3' UTR variant c. $3782 \mathrm{~T}>\mathrm{C}$ was predicted to cause the addition of a stem loop at the position of the variant. This nucleotide is not conserved in the murine Bach1/Brip1 gene, however, so may not, therefore, be functionally significant. The 3401 delC variant was predicted to cause a frameshift resulting in a premature stop codon 15 amino acids downstream. This would truncate the protein by 100 amino acid residues. The intronic changes and the other exonic variants, c. $517 \mathrm{C}>\mathrm{T}$ (p. R172C) and c. $3411 \mathrm{~T}>\mathrm{C}$ (p. T1137T), were all found in at least one control, indicating that they are likely to be benign polymorphisms.

DNA samples from additional family members of the c. 430 $\mathrm{G}>\mathrm{A}$, c. $584 \mathrm{~T}>\mathrm{C}$, c. $3464 \mathrm{G}>\mathrm{A}$, and the c. $3401 \mathrm{delC}$ carriers were available for analysis, but none of these variants were found to segregate with breast cancer in the families. Both the c.430 G>A and c.3401delC variants were inherited from the father of the index case who had no personal or family history of breast cancer, and not from the affected mother with a strong family history. The c.584 $\mathrm{T}>\mathrm{C}$ variant was identified in only the unaffected father and uncle of the index case, and not in 24 other relatives (including two other affected females). Finally, the c.3464 G>A variant was found in a family in which the index case shared a haplotype around $B R I P 1 / B A C H 1$ with four affected maternal relatives, but only the index case carried the variant, indicating that it was inherited from her father who had no personal or family history of breast cancer.

Analysis of exons 3 and 7 of $B R I P 1 / B A C H 1$ in a further 253 non-BRCA1/BRCA2 breast cancer index cases did not identify the p. P47A and p. M299I variants previously reported, or any other variants.

\section{LMO4}

Index cases from 247 families were screened by DHPLC across the three coding exons of LMO4. Using the primers designed to amplify exon 3, two intronic variations were observed in two individuals each, c.237-72T>G and c.23751_237-46delTTCTTT, but no coding variants were identified.

\section{SFN}

DHPLC analysis of most (639/747 bp) of the coding exon of SFN of the youngest available member affected with breast cancer of each of 256 families identified one silent variant, c.621 C>T (T207T) in 23 index cases. One individual was found to carry three missense alterations (c.594C $>A$ (F198L), c.653C $>A(L 218 \mathrm{I})$ and c.730C $>A(Q 244 \mathrm{~K}))$. In the 92 individuals screened for the remaining 89 bp SFN coding region, 10 different alterations were observed in the $3^{\prime}$ UTR in 11 cases (c.748G $>C, \quad$ c.765C $>\mathrm{T}, \quad$ c.766C $>A, \quad$ c.767C $>\mathrm{T}$, c. $775 \mathrm{C}>\mathrm{A}$, c.776C $>\mathrm{T}$, c.777C $>\mathrm{T}$, c.786C $>\mathrm{A}$, c.787C $>\mathrm{A}$, and c.792C>T). Several of these were predicted to affect the secondary structure of the corresponding transcript (Table 3).

\section{Discussion}

Previous analyses of $F A N C D 2$ and $B R I P 1 / B A C H 1$ in non$B R C A 1 / 2$ families failed to identify any pathogenic mutations $[14,16,17]$; however, these studies did not choose the families to be screened on the basis of haplotype sharing, or the occurrence of other cancers (e.g. ovarian cancer in the case of FANCD2) in the family. Furthermore, some of these studies were limited by the fact that DNA from additional family members was not available for genotyping. To our knowledge, LMO4 and SFN have not been previously examined as $B R C A x$ candidate genes. We therefore hypothesized that germline mutations in the BRCA1-interacting genes, FANCD2, BRIP1/BACH1, LMO4 and SFN, may account for 
some non-BRCA1/2 multiple-case breast cancer families. LMO4 and SFN are both small genes and so 247 and 267 index cases, respectively, were screened for these two genes. Because of the large size of the FANCD2 and BRIP1/BACH1 genes, however, we screened a smaller number of non$B R C A 1 / 2$ breast cancer families for mutations in these genes (30 and 75 families, respectively), but they were selected on the basis of all the available affected individuals sharing a haplotype around FANCD2 or BRIP1/BACH1, having at least one case of ovarian cancer (FANCD2), or having had full sequence analysis of $B R C A 1$ and $B R C A 2$ (BRIP1/BACH1). In addition, we screened a further 399 and 253 cases, respectively, for specific regions of the FANCD2 and BRIP1/BACH1 genes that contained functionally important domains, or variants previously found in the germline of breast cancer cases.

DHPLC analysis the FANCD2 gene indicated a high level of conservation in the coding sequence, indicated by a paucity of missense changes. Only six coding variants (c. $633 \mathrm{C}>\mathrm{T}$, $1122 \mathrm{~A}>\mathrm{G}, 1440 \mathrm{~T}>\mathrm{C}, 1509 \mathrm{C}>\mathrm{T}, 2148 \mathrm{C}>\mathrm{G}$ and $3558 \mathrm{C}>\mathrm{G}$ ) were identified in the FANCD2 gene, all of which were silent. c.633 C>T and $2148 \mathrm{C}>\mathrm{G}$ did not appear to dramatically affect the predicted RNA splicing or folding by in silico analyses and were, therefore, assumed to be neutral SNPs. 3558 C>G (L1186L) was suggested by the BDGP Splice site predictor program (but not SpliceSiteFinder) to result in the complete loss of the donor site, possibly resulting in the misplicing of exon 35. RT-PCR analysis of a lymphoblastoid cell line from the carrier failed, however, to identify any aberrant transcripts, suggesting that this variant is unlikely to be pathogenic. The L $1186 \mathrm{~L}$ variant was not identified in any of 93 controls, but it did not segregate with breast cancer in the single family in which it was found. Therefore, this variant was also assumed to be a rare, neutral SNP.

Two common haplotypes of the FANCD2 gene were identified, one of which (haplotype B) was identical to the reference sequence obtained from the NCBI database. All of the rare variants were found to occur on haplotype B. Even though individually these variants were classified as neutral SNPs, an association study designed to test whether the two haplotypes confer different breast cancer risks would be worthwhile.

In the analysis of the BRIP1/BACH1 gene, we did not observe the two previously reported variants, p. P47A and p. M299l, in the 253 non-BRCA1/2 breast cancer cases [15]. However, we did identify three non-conservative missense variants ( $p$. A144T, p. L195P, and p. G1155E) and one novel frameshift mutation (c. $3401 \mathrm{delC}$ ) in the 75 selected non-BRCA1/ $B R C A 2$ breast cancer index cases. None of these variants were found in 93 controls. Additional genotyping of a total of 68 family members indicated, however, that these variants are not the underlying cause of breast cancer in these families, as none of the other affected relatives carried the variants. Nevertheless, it is possible that these variants are low-risk breast cancer susceptibility alleles, in which case further investigation may be warranted. The $3782 \mathrm{~T}>\mathrm{C}$ 3' UTR variant of BRIP1/ $B A C H 1$ is predicted to alter the folding of the transcript; however, the biological significance and frequency of this change in the normal population has yet to be determined.

Mutation analysis of 82 sporadic tumours previously revealed one somatic frameshift mutation of $L M O 4$ [22]. No activating or inactivating coding or splice site mutations of $\mathrm{LMO} 4$ were found by DHPLC analysis of 247 index cases from non$B R C A 1 / 2$ families. Two intronic variants were found, each in two index cases. Their recurrent nature in two families and apparent lack of effect on splicing suggests that they are rare SNPs.

SFN is markedly down-regulated in breast cancer tissue compared to normal mammary epithelium but to our knowledge has not been evaluated for germline mutations in familial breast cancer. We screened the majority of the coding region of the gene in 267 index cases and found one silent change, T207T, in 23 index cases. This silent change has been previously reported (rs11542704) [43]. We also found some variants in the $3^{\prime}$ UTR, and three different missense changes in one individual (F198L, L218I and Q244K) that were considered unlikely to be pathogenic because of the multiple occurrences in one individual. None of these variants have been previously reported.

\section{Conclusion}

Mutation analysis of the BRCA1-interacting genes FANCD2, $B R I P 1 / B A C H, L M O 4$ and SFN in a large number of non$B R C A 1 / 2$ breast cancer families did not identify any highly penetrant, pathogenic mutations. Given that DHPLC is a robust and sensitive screening technique, we consider it unlikely that we missed any coding or splice site pathogenic mutations among the index cases analysed. In particular, we analysed each PCR fragment at all the temperatures recommended by the DHPLC melt algorithm and under these conditions DHPLC has been reported to have a sensitivity of $99.4 \%$ [40]. It appears unlikely, therefore, that FANCD2, BRIP1/ $B A C H, L M O 4$ and SFN account for more than a small proportion of inherited forms of breast cancer. Many novel SNPs were identified in these genes, however, and large association studies of breast cancer cases and controls is warranted to determine whether any of these variants confer small risks of breast cancer.

\section{Competing interests}

The authors declare that they have no competing interests.

\section{Authors' contributions}

GCT, GL, JV and JF were responsible for the design of this study and GCT, JF and AL drafted the manuscript. AL, JF, and AM performed the experimental work. Haplotype sharing data were provided by GP and GM. Clinical and genetic data, and 
biospecimens, were provided by kConFab. MAB assisted with analysis of mFOLD data, and with preparation of the manuscript.

\section{Acknowledgements}

The authors would like to thank Melissa Southey for discussion of the splice site variants, Heather Thorne, Lynda Williams, Dani Surace and Lana Tarcova for DNA preparation, the kConFab research nurses and staff of the Familial Cancer Clinics for data collection, the kConFab Central Registry staff and Helene Holland for supplying data, and the families for their participation. This research was supported by a Programme grant from the National Health and Medical Research Council of Australia to GCT. kConFab is supported by the National Breast Cancer Foundation, the National Health and Medical Research Council of Australia, and the Cancer Councils of Queensland, New South Wales, Western Australia, South Australia, and Victoria. ABS is/has an NHMRC Career Development Award, and GCT, GL and JV are NHMRC Research Fellows.

\section{References}

1. Ford D, Easton DF, Stratton M, Narod S, Goldgar D, Devilee P, Bishop DT, Weber B, Lenoir G, Chang-Claude J, et al:: Genetic heterogeneity and penetrance analysis of the BRCA1 and BRCA2 genes in breast cancer families. The Breast Cancer Linkage Consortium. Am J Hum Genet 1998, 62:676-689.

2. Moll UM, Riou G, Levine AJ: Two distinct mechanisms alter p53 in breast cancer: mutation and nuclear exclusion. Proc Natl Acad Sci USA 1992, 89:7262-7266.

3. Shugart YY, Cour C, Renard H, Lenoir G, Goldgar D, Teare D, Easton D, Rahman N, Gusterton R, Seal S, et al.: Linkage analysis of 56 multiplex families excludes the Cowden disease gene PTEN as a major contributor to familial breast cancer. J Med Genet 1999, 36:720-721.

4. Chenevix-Trench G, Spurdle AB, Gatei M, Kelly H, Marsh A, Chen X, Donn K, Cummings M, Nyholt D, Jenkins MA, et al.: Dominant negative ATM mutations in breast cancer families. J Nat/ Cancer Inst 2002, 94:205-215.

5. Meijers-Heijboer $\mathrm{H}$, van den Ouweland A, Klijn J, Wasielewski M, de Snoo A, Oldenburg R, Hollestelle A, Houben M, Crepin E, van Veghel-Plandsoen $M$, et al.: Low-penetrance susceptibility to breast cancer due to $\mathrm{CHEK} 2\left(^{*}\right) 1100 \mathrm{delC}$ in noncarriers of BRCA1 or BRCA2 mutations. Nat Genet 2002, 31:55-59.

6. Meetei AR, de Winter JP, Medhurst AL, Wallisch M, Waisfisz $Q$, van de Vrugt $\mathrm{HJ}$, Oostra AB, Yan Z, Ling C, Bishop CE, et al:: A novel ubiquitin ligase is deficient in Fanconi anemia. Nat Genet 2003, 35:165-170.

7. Bagby GC Jr: Genetic basis of Fanconi anemia. Curr Opin Hematol 2003, 10:68-76.

8. Grompe M, D'Andrea A: Fanconi anemia and DNA repair. Hum Mol Genet 2001, 10:2253-2259.

9. D'Andrea $A D$, Grompe $M$ : The Fanconi anaemia/BRCA pathway. Nat Rev Cancer 2003, 3:23-34.

10. Houghtaling S, Timmers C, Noll M, Finegold MJ, Jones SN, Meyn MS, Grompe M: Epithelial cancer in Fanconi anemia complementation group D2 (Fancd2) knockout mice. Genes Dev 2003, 17:2021-2035

11. McAllister KA, Bennett LM, Houle CD, Ward T, Malphurs J, Collins NK, Cachafeiro C, Haseman J, Goulding EH, Bunch D, et al: Cancer susceptibility of mice with a homozygous deletion in the $\mathrm{COOH}$-terminal domain of the Brca2 gene. Cancer Res 2002, 62:990-994.

12. Taniguchi T, Tischkowitz M, Ameziane N, Hodgson SV, Mathew CG, Joenje H, Mok SC, D'Andrea AD: Disruption of the Fanconi anemia-BRCA pathway in cisplatin-sensitive ovarian tumours. Nat Med 2003, 9:568-574.

13. Lounis H, Mes-Masson AM, Dion F, Bradley WE, Seymour RJ, Provencher D, Tonin PN: Mapping of chromosome 3p deletions in human epithelial ovarian tumours. Oncogene 1998, 17:2359-2365.

14. Seal $S$, Barfoot $R$, Jayatilake $H$, Smith $P$, Renwick $A$, Bascombe $L$, McGuffog L, Evans DG, Eccles D, Easton DF, et al.: Evaluation of
Fanconi Anemia genes in familial breast cancer predisposition. Cancer Res 2003, 63:8596-8599.

15. Cantor SB, Bell DW, Ganesan S, Kass EM, Drapkin R, Grossman S, Wahrer DC, Sgroi DC, Lane WS, Haber DA, et al.: BACH1, a novel helicase-like protein, interacts directly with BRCA1 and contributes to its DNA repair function. Cell 2001, 105:149-160.

16. Karppinen SM, Vuosku J, Heikkinen K, Allinen M, Winqvist R: No evidence of involvement of germline $\mathrm{BACH} 1$ mutations in Finnish breast and ovarian cancer families. Eur J Cancer 2003, 39:366-371.

17. Rutter JL, Smith AM, Davila MR, Sigurdson AJ, Giusti RM, Pineda MA, Doody MM, Tucker MA, Greene MH, Zhang J, et al:: Mutational analysis of the BRCA1-interacting genes ZNF350/ ZBRK1 and BRIP1/BACH1 among BRCA1 and BRCA2-negative probands from breast-ovarian cancer families and among early-onset breast cancer cases and reference individuals. Hum Mutat 2003, 22:121-128.

18. Rabbitts TH: LMO T-cell translocation oncogenes typify genes activated by chromosomal translocations that alter transcription and developmental processes. Genes Dev 1998, 12:2651-2657.

19. Visvader JE, Venter D, Hahm K, Santamaria M, Sum EY, O'Reilly L, White D, Williams R, Armes J, Lindeman GJ: The LIM domain gene LMO4 inhibits differentiation of mammary epithelial cells in vitro and is overexpressed in breast cancer. Proc Natl Acad Sci USA 2001, 98:14452-14457.

20. Sum EY, Segara D, Duscio B, Bath ML, Field AS, Sutherland RL, Lindeman GJ, Visvader JE: Overexpression of LMO4 induces mammary hyperplasia, promotes cell invasion, and is a predictor of poor outcome in breast cancer. Proc Natl Acad Sci USA 2005, 102:7659-7664.

21. Sum EY, Peng B, Yu X, Chen J, Byrne J, Lindeman GJ, Visvader JE: The LIM domain protein LMO4 interacts with the cofactor CtIP and the tumour suppressor BRCA1 and inhibits BRCA1 activity. J Biol Chem 2002, 277:7849-7856.

22. Sutherland KD, Visvader JE, Choong DY, Sum EY, Lindeman GJ, Campbell IG: Mutational analysis of the LMO4 gene, encoding a BRCA1-interacting protein, in breast carcinomas. Int $J$ Cancer 2003, 107:155-158.

23. Prasad GL, Valverius EM, McDuffie E, Cooper HL: Complementary DNA cloning of a novel epithelial cell marker protein HME1, that may be down-regulated in neoplastic mammary cells. Cell Growth Differ 1992, 3:507-513.

24. Ferguson AT, Evron E, Umbricht CB, Pandita TK, Chan TA, Hermeking $\mathrm{H}$, Marks JR, Lambers AR, Futreal PA, Stampfer MR, et al: High frequency of hypermethylation at the 14-3-3 sigma locus leads to gene silencing in breast cancer. Proc Natl Acad Sci USA 2000, 97:6049-6054.

25. Umbricht CB, Evron E, Gabrielson E, Ferguson A, Marks J, Sukumar S: Hypermethylation of 14-3-3 sigma (stratifin) is an early event in breast cancer. Oncogene 2001, 20:3348-3353.

26. Laronga $\mathrm{C}$, Yang HY, Neal C, Lee MH: Association of the cyclindependent kinases and 14-3-3 sigma negatively regulates cell cycle progression. J Biol Chem 2000, 275:23106-23112.

27. Aprelikova O, Pace AJ, Fang B, Koller BH, Liu ET: BRCA1 is a selective co-activator of 14-3-3 sigma gene transcription in mouse embryonic stem cells. J Biol Chem 2001, 276:25647-25650

28. van 't Veer LJ, Dai $H$, van de Vijver MJ, He YD, Hart AA, Mao M, Peterse HL, van der Kooy K, Marton MJ, Witteveen AT, et al.: Gene expression profiling predicts clinical outcome of breast cancer. Nature 2002, 415:530-536.

29. Borg $A$, Zhang $\mathrm{QX}$, Olsson $\mathrm{H}$, Wenngren $\mathrm{E}$ : Chromosome 1 alterations in breast cancer: allelic loss on $1 p$ and $1 q$ is related to lymphogenic metastases and poor prognosis. Genes Chromosomes Cancer 1992, 5:311-320.

30. Tsukamoto K, Ito N, Yoshimoto M, Kasumi F, Akiyama F, Sakamoto G, Nakamura Y, Emi M: Allelic loss on chromosome 1p is associated with progression and lymph node metastasis of primary breast carcinoma. Cancer 1998, 82:317-322.

31. Millikan RC, Ingles SA, Diep AT, Xue S, Zhou N, Florentine BD, Sparkes RS, Haile RW: Linkage analysis and loss of heterozygosity for chromosome arm 1p in familial breast cancer. Genes Chromosomes Cancer 1999, 25:354-361.

32. Osborne RH, Hopper JL, Kirk JA, Chenevix-Trench G, Thorne HJ, Sambrook JF: kConFab: a research resource of Australasian breast cancer families. Kathleen Cuningham Foundation Con- 
sortium for Research into Familial Breast Cancer [letter]. Med $J$ Aust 2000, 172:463-464.

33. Rozen S, Skaletsky H: Primer3 on the WWW for general users and for biologist programmers. Methods Mol Biol 2000, 132:365-386.

34. Jones AC, Austin J, Hansen N, Hoogendoorn B, Oefner PJ, Cheadle JP, O'Donovan MC: Optimal temperature selection for mutation detection by denaturing HPLC and comparison to single-stranded conformation polymorphism and heteroduplex analysis. Clin Chem 1999, 45:1133-1140.

35. Spiegelman Jl, Mindrinos MN, Oefner PJ: High-accuracy DNA sequence variation screening by DHPLC. Biotechniques 2000, 29:1084-1090. 1092

36. Karolchik D, Baertsch R, Diekhans M, Furey TS, Hinrichs A, Lu YT, Roskin KM, Schwartz M, Sugnet CW, Thomas DJ, et al.: The UCSC Genome Browser Database. Nucleic Acids Res 2003, 31:51-54.

37. Reese MG, Eeckman FH, Kulp D, Haussler D: Improved splice site detection in Genie. J Comput Biol 1997, 4:311-323.

38. Cartegni L, Wang J, Zhu Z, Zhang MQ, Krainer AR: ESEfinder: A web resource to identify exonic splicing enhancers. Nucleic Acids Res 2003, 31:3568-3571.

39. Zuker M: Mfold web server for nucleic acid folding and hybridization prediction. Nucleic Acids Res 2003, 31:3406-3415.

40. Frueh FW, Noyer-Weidner M: The use of denaturing high-performance liquid chromatography (DHPLC) for the analysis of genetic variations: impact for diagnostics and pharmacogenetics. Clin Chem Lab Med 2003, 41:452-461.

41. SpliceSiteFinder [http://www.genet.sickkids.on.ca/ ali/splices itefinder.html]

42. NCBI [http://www.ncbi.nlm.nih.gov/]

43. Celera [http://www.celera.com/]

44. SNPper [http://snpper.chip.org/bio/]

45. Fanconi Anemia Mutation Database [http://www.rockefel ler.edu/fanconi/mutate/] 